\title{
Concrete and Selection of Concrete
}

\author{
Khalil Tabatabaei $^{{ }^{*}}$, FarhadTabatabaei $^{2}$ \\ ${ }^{1}$ Civil- University Student of Miandoab, Iran \\ ${ }^{2}$ Civil- Road Transport, Urmia University, Iran
}

*Corresponding Author: Khalil Tabatabaei, Civil- University Student of Miandoab, Iran

\begin{abstract}
Formwork system is an essential component in deciding the construction project duration. It has been found from various research studies that progress of projects is dependent on factors like speed, buildability, constructability, and safety in use of the formwork systems. In typical Reinforced Cement Concrete (RCC) building construction, cost of formwork accounts significantly. A rough estimate shows that it is about 40 to 60 percent of the cost of concrete frame and roughly equal to 10 percent of the total cost of the building structure. Further, it is found major component of this cost is labour dependent and poses a significant control over safety, speed and competency. In the present work, an attempt has been made to study the factors influencing the selection of formwork system. Traditional and modern formwork systems are studied using a questionnaire survey to assess selection factors. The crucial factors, which were considered for different formwork systems such as traditional formwork, Mivan, and Doka, are cost, quality, cycle time, number of repetitions, and safety. This research study will help construction project contractors to select appropriate formwork system for safe and economical concrete construction.
\end{abstract}

Keywords: Building; Construction; Concrete;Methodology; Formwork;RCC.

\section{INTRODUCTION}

Construction industry in India has begun utilizing a portion of the excellent innovations. A few formwork frameworks are being used at better places on the planet; in the long run the frameworks which are sensibly temperate and simple for activity with talented work are more valuable in India. Formwork framework has noteworthy part in the development procedure; making the privilege choice by picking the suitable formwork framework could prompt reaction to reasonable development. Distinctive frameworks have their own particular preferences however one needs to pick a formwork which best backings singular venture necessity. Lack/non accessibility talented and semi gifted specialists brings about issues of cost and time over-runs, second rate development, poor completions spillages, erosion of structures and so on this can be maintained a strategic distance from by receiving current formwork frameworks. This additionally stays away from repairs and recovery of structures before its normal life expectancy. Use of formwork had become extensive in construction industry, mainly because of the advantages it offers like of quicker execution of the projects and good outcomes in terms of quality of construction.

\section{SigNIFICANCE OF THE STUdY}

One of the critical factors, which account for the success of any construction project, is the formwork systems. Formwork systems play a significant role in finishing the construction of projects within the stipulated duration. Selecting the right type of formwork system is very important parameter so that the construction projects are completed within the budget and duration. Generally, the contractors to find out the best suitable formwork system to use carry out comprehensive analysis. Cost of construction can be reduced significantly by selecting an effective formwork system as it a major contributor to the overall cost of the project. Hence identifying a proper formwork system is very important for the success of construction projects.

\section{LITERATURE REVIEW}

Haronetal, (2013) did investigation of Malaysian construction industry in context to the cost comparison of the conventional system and industrialized building system (IBS) of formwork system. The methodology adopted was a structured questionnaires based analysis, which was validated by a 
case study. Authors used stastical T test and concluded that was significant difference in the cost reduction for the two systems. Karke and Kumthekar (2014) compared the advantages and disadvantages of timber formwork with the modern formwork techniques. The factors that were included in their study were time, cost and quality of the formwork systems. Project site data was used for collected from different sites and comparison was done. Modern systems studied were MIVAN and Tunnel formwork. They concluded that using the modern formwork systems there is a reduction in the cycle time of construction, thereby reducing the overall project cost. Kazi and Parkar, (2015), analyzed the conventional and latest formwork techniques. They found that adoption of new systems of formwork construction facilitates casting of large structural members in a single pour of casting. This will reduce time and labour dependency as compared to conventional methods. Thus, the different new systems have an upper hand in achieving economy, good quality of construction at a relatively faster rate.

Ganar A and Patil S (2015), in their study did cost analysis of the MIVAN formwork systems and conventional formwork systems for a 12 storied RCC building. From their analysis, they concluded that the MIVAN formwork will cost about 14.04 percent less than the conventional system and time required for the construction will be half as compared to conventional system.

Pawar S and Atterde P (2014), in their study used case study approach and found that same organization using two different types of the formwork systems on their different projects, reduction in the time and cost was observed. The cost saving was found due to use of latest formwork systems. Taher A et al (2009) in their review paper carried out an extensive literature to benchmark the sustainable formwork systems. They divided their work in three critical categories, environmental such as (Waste generation, Using renewable material, Formwork reusable, and Material efficiency), economical such as (installation cost, cost in-use, Life cycle cost, and Formwork serviceability), and social such as (Safety assessment \& safety design of formwork system, Direct employment, and fire resistance). They found that a Sustainable formwork system could be adopted by benchmarking three critical categories; environmental, economical, and social, which will involve all the parameters incorporated in the selection of formwork systems. Hanna, A. S. (1999) stated the best practices for conventional system, its advantages and limitations. Conventional wooden formwork is usually referred to as stick-form or hand over hand method. Conventional system includes formwork for beams, slabs and for foundations. The system was built with lumber or in combination of lumber and plywood. Formwork pieces are made and erected in situ, for stripping, they are stripped piece by piece, then cleaned, and can be reused very less times. Pitroda and Bhavsar (2015), analysed aluminum formwork systems in Indian conditions. Their methodology was based on a case approach, from which they concluded that if aluminum is used as a formwork material it will result in saving of cost and speed of construction will be fast. Further, they found that is lightweight so ease of use is also from point of view of labours. Wani (2017) did a case study based analysis of Pune city for implementation of new formwork techniques used. It was observed from the study that though initial cost of the DOKA formwork is high but this increased cost will be reduced by good finishing and less time of construction as compared to other formwork system used. Table 1 shows comparison between different parameters of the various systems used in construction projects.

Table1. Comparison of Mivan, Doka and Conventional Formwork Systems

\begin{tabular}{|c|c|c|c|c|}
\hline Sr. No & Characteristics & $\begin{array}{c}\text { MIVAN } \\
\text { System }\end{array}$ & Doka Systems & $\begin{array}{c}\text { Conventional } \\
\text { Formwork System }\end{array}$ \\
\hline 1. & Floor cycle & $\begin{array}{c}\text { Four days cycle } \\
\text { per floor. }\end{array}$ & $\begin{array}{c}\text { Seven to eight days } \\
\text { cycle per floor. }\end{array}$ & $\begin{array}{c}\text { Min. cycle time is of 21 } \\
\text { days. }\end{array}$ \\
\hline 2. & Finish quality & Best & Best & No need of plastering \\
\hline 3. & Pre-planning of formwork & Essential & Desirable \\
\hline 4. & Type of construction & $\begin{array}{c}\text { Modular } \\
\text { construction }\end{array}$ & Cellular construction & $\begin{array}{c}\text { RCC framed } \\
\text { construction }\end{array}$ \\
\hline 5. & Wastage of formwork material & less & less & Less \\
\hline 6. & Precision in construction & Good & Essential & Desirable \\
\hline 7. & $\begin{array}{c}\text { Coordination between } \\
\text { different agencies }\end{array}$ & Essential & Better & Less \\
\hline 8. & Resistance to earthquake & Better & Less & More \\
\hline 9. & Stripping time required & Less & \\
\hline
\end{tabular}




\begin{tabular}{|c|c|c|c|c|}
\hline 10. & Timber use & Not required & Not required & $\begin{array}{c}\text { Essential component of } \\
\text { the system }\end{array}$ \\
\hline 11. & Number of repetitions possible & $250-300$ & $250-300$ & Maximum 50 \\
\hline 12. & $\begin{array}{l}\text { Possible use for High rise } \\
\text { structures }\end{array}$ & Best choice & Good choice & Difficult \\
\hline 13. & $\begin{array}{c}\text { Initial investment in the } \\
\text { system }\end{array}$ & High & High & $\begin{array}{c}\text { Less in comparison to } \\
\text { modern systems }\end{array}$ \\
\hline 14. & Economy in construction & $\begin{array}{l}\text { Economica } 1 \text { for } \\
\text { mass housing }\end{array}$ & $\begin{array}{c}\text { Economical for mass } \\
\text { housing }\end{array}$ & May prove costly \\
\hline
\end{tabular}

(Source: Adopted and modified from Karke and Kumthekar 2014)

\section{Methodology}

The methodology of the present study was divided in the three phases and the details of the same are discussed below.

\subsection{Preparation of Survey Questionnaire}

For the preparation of questionnaire, a detailed study of the literature was done to identify the various factors considered before the selection of formwork. It was observed from the literature review that factors that were identified by different authors were primarily related to initial cost of formwork, quality of concrete finishing, safety measures, possibility of reuse. Based on the factors questionnaire was framed.

\subsection{Data Collection Using Survey Questionnaire}

The questionnaire was sent to population that included respondent from different firms like contracting, client, consultants etc. The questionnaire adopted a 5-point likert scale ranging from 5 (strongly agree) to 1 (strongly disagree), the higher the number, the greater the influence on type of formwork system selection. The data was collected using structured questionnaires on a 5- point Likert scale. Respondents were asked to give their opinion about the factor and rank their choice, which will have major impact on selecting the formwork systems based on their expertise.

\subsection{Data Analysis}

Relative Importance Index (RII) was used for calculating the rank of three factors that are important for selection of formwork systems. Analysis was carried out using the relation as given in equation 1.

Relative Importance Index RII = Sum of weights $(\mathrm{W} 1+\mathrm{W} 2+\mathrm{W} 3+\ldots+\mathrm{Wn}) / \mathrm{A}$ x N... 1

$\mathrm{W}=$ weights given to each factor by the respondents.

A $=$ highest weight of that factor as assigned ( 5 in this study).

$\mathrm{N}=$ total number of responses given by the respondents for that factor.

\section{ReSUlts}

A total of 51 responses were received whereas 65 questionnaires were circulated. Demographic analysis is shown Table 2. The analysis was carried out as discussed above and the results of the same are presented in Table 3.

Table2. Demographic Details of the Respondents

\begin{tabular}{|c|c|c|}
\hline Demographic Parameters & Criteria & Number of respondents \\
\hline \multirow{4}{*}{ Qualification } & Diploma & 15 \\
\cline { 2 - 3 } & Degree & 26 \\
\cline { 2 - 3 } & Post Graduation & 5 \\
\cline { 2 - 3 } & Architecture & 5 \\
\hline \multirow{4}{*}{ Work Experience in years } & Less than 5 years & 4 \\
\cline { 2 - 3 } & 5 to 10 years & 14 \\
\cline { 2 - 3 } & 10 to 15 years & 26 \\
\cline { 2 - 3 } & More than 15 years & 7 \\
\hline \multirow{4}{*}{ Designation } & Trainee & 6 \\
\cline { 2 - 3 } & Site Engineer & 17 \\
\cline { 2 - 3 } & Senior Engineer & 7 \\
\cline { 2 - 3 } & Project Manager & 11 \\
\cline { 2 - 3 } & &
\end{tabular}


Table3. Ranking Of Different Parameters and Types of Formwork Systems Using RII

\begin{tabular}{|c|c|c|}
\hline \multicolumn{2}{|l|}{ Conventional Formwork } & \multirow[b]{2}{*}{ Rank } \\
\hline Parameters /Criteria for selection & RII & \\
\hline Safety measures to be adopted during erection. & 0.54 & 1 \\
\hline Quality of Concrete after casting & 0.50 & 2 \\
\hline Initial Cost of the formwork system & 0.47 & 3 \\
\hline Time needed for erection and stripping & 0.46 & 4 \\
\hline Possibility of Reuse & 0.45 & 5 \\
\hline Requirement of skilled labour & 0.44 & 6 \\
\hline Necessity of training for adoption of that material/technique & 0.42 & 7 \\
\hline \multicolumn{3}{|l|}{ Mivan Formwork } \\
\hline Parameters /Criteria for selection & RII & Rank \\
\hline Safety measures to be adopted during erection. & 0.82 & 1 \\
\hline Quality of Concrete after casting & 0.80 & 2 \\
\hline Initial Cost of the formwork system & 0.78 & 3 \\
\hline Possibility of Reuse & 0.77 & 4 \\
\hline Requirement of skilled labour & 0.72 & 5 \\
\hline Necessity of training for adoption of that material/technique & 0.72 & 6 \\
\hline Time needed for erection and stripping & 0.68 & 7 \\
\hline \multicolumn{3}{|l|}{$\begin{array}{l}\text { Doka Formwork } \\
\end{array}$} \\
\hline Parameters /Criteria for selection & RII & Rank \\
\hline Safety measures to be adopted during erection. & 0.82 & 1 \\
\hline Quality of Concrete after casting & 0.80 & 2 \\
\hline Initial Cost of the formwork system & 0.78 & 3 \\
\hline Possibility of Reuse & 0.76 & 4 \\
\hline Requirement of skilled labour & 0.72 & 5 \\
\hline Necessity of training for adoption of that material/technique. & 0.71 & 6 \\
\hline Time needed for erection and stripping & 0.65 & 7 \\
\hline
\end{tabular}

(Source: Compiled by Authors)

\section{CONCLuSion}

It was observed from the different studies that there is a need for fast construction techniques. In addition, initial cost of formwork is also an important criteria in selection. In case of large projects with more number of repetitions and modular construction, latest formwork will always have an advantage over conventional. However, hurdle in the same is the constraints like available manpower for erection, their trainings and safety measures. It is observed from the results, that in all the type of formwork systems viz, Conventional, Mivan and Doka three factors which are listed below have been given more significance by the respondents. 1. Safety measures to be adopted during erection.

2. Quality of Concrete after casting 3. Initial Cost of the formwork system.

It is observed that in all the three-formwork systems, respondents have given more importance to safety during the erection. Further, all the systems have been rated quality of concrete after casting. However, this quality will have more importance for conventional system as compared to the other two, as repeated use of the same may decrease the quality for conventional formwork. Therefore, if conventional formwork is selected for any projects, care should be taken while stripping of the formwork as wear and tear, cleaning will have a significant impact on quality.

\section{REFERENCES}

[1] Ganar, A. S., \&Patil, S. D. (2015). Comparative analysis on cost and duration of MIVAN formwork building and Conventional Formwork building. International Journal on Recent and Innovation Trends in Computing and Communication, 3(12).

[2] Hanna, A. S., \& Hanna, A. S. (1999). Concrete formwork systems. New York: Marcel Dekker.

[3] Rahim, M. S. M., \&Haron, N. A. (2013). Construction cost comparison between conventional and formwork system for condominium project. International Journal of Advanced Studies in Computers, Science and Engineering, 2(5), 19. 
[4] Karke S and Kumthekar M (2009). Comparison of the use of Traditional and Modern Formwork Systems, Civil Engineering Systems and Sustainable Innovations, ISBN: 978-93-83083-78-7.

[5] Kazi ,A. \&Parkar F,.(2015). Comparative Study And Decision Making For A Formwork Technique To Be Adopted On A Construction Site In Mumbai. International Journal of Research in Engineering and Technology, Volume 04 Issue 12.

[6] Patel,M., Pitroda J, Bhavsar J (2015), Recent Scenario in Formwork: Aluminium Forms, International Conference on: "Engineering: Issues, opportunities and Challenges for Development.

[7] Patil D S, Desai D B. Emerging Trends in Formwork Cost Analysis \& Effectiveness of Mivan Formwork over the Conventional Formwork Journal of Mechanical and Civil Engineering ISSN: 2278-1684, pp 2730.

[8] Pawar, S. P., \&Atterde, P. M. (2014). Comparative Analysis of Formwork in Multistory Building. International Journal of Research in Engineering and Technology, 3(9), 22-24.

[9] TaherA,.Rozana, Z, Rosli,M.(2009) Benchmarks for Sustainable Formwork System”, International Conference on Sustainable Infrastructure and Built Environment in Developing Countries , Bandung , West Java, Indonesia ISBN 978-979-98278-2-1.

[10] Wani B,.(2017) Analysis of New Formwork Technology Adopted on a Construction Site in Pune, International Journal Of Innovations In Engineering Research and Technology Volume 4, Issue 11, Nov.2017 pp 11-15.

Citation: Khalil tabatabaei \& farhad tabatabaei "Concrete and Selection of Concrete", International Journal of Constructive Research in Civil Engineering, 5(4), pp. 1-5. DOI: http://dx. doi.org/10.20431/24548693.0504001

Copyright: (C) 2019 Authors, This is an open-access article distributed under the terms of the Creative Commons Attribution License, which permits unrestricted use, distribution, and reproduction in any medium, provided the original author and source are credited. 